Bojan D Krstić ${ }^{1}$

Nevena Stanisavljević ${ }^{2}$

Tanja Stanišić ${ }^{3}$
JEL: L14

DOI: 10.5937/industrija42-6035

UDC: 005.642.1:334.7(497.11)

Original Scientific Paper

\title{
Generic Benchmarking in the aim of Improving Clusters' Performances in Serbia ${ }^{4}$
}

Article history:

Received: 15 April 2014

Sent for revision: 24 May 2014

Received in revised form: 8 September 2014

Accepted: 12 September 2014

Available online: 1 November 2014

\begin{abstract}
By the generic benchmarking, cluster organizations can reduce risk, and allow better use of own development potentials. The purpose of this paper is to establish a methodological framework for benchmarking of cluster organizations in Serbia. The examination of the formation, functioning and development process of cluster organizations, as well as the existing benchmarking methodologies in European clusters, was used to set up a customized methodological framework for benchmarking in this paper. The applicability of the recommended methodology is verified by the realization of a comparative study between two cluster organizations in Serbia. The result of this benchmarking of clusters' performances represents, among others, determined set of measures and actions to improve the business performances of the Medical Start up Cluster. The research is useful not only to creators of regional development policies, providing a useful benchmarking methodology, but also to the management of cluster organizations in Serbia, by providing them with a tool which if continuously applied may improve the performances of cluster members and cluster organizations as a whole.
\end{abstract}

Key words: cluster, performance, benchmarking, process, activity

\footnotetext{
${ }^{1}$ University of Nis, Faculty of Economics, bojan.krstic@eknfak.ni.ac.rs

${ }^{2}$ University of Nis, Faculty of Economics

${ }^{3}$ University of Nis, Faculty of Mathematics and Science

${ }^{4}$ The paper was supported by the Ministry of Education, Science and Technological

Development, Republic of Serbia (Project 179066)
} 
Krstić D.B. et al.: Generic Benchmarking in the aim of Improving Clusters'...

\section{Generički benčmarking u cilju unapredjenja performansi klastera u Srbiji}

Apstrakt: Pomoću generičkog benčmarkinga, klasterske organizacije mogu da smanje rizik i obezbede bolje iskorišćavanje svojih razvojnih potencijala. Svrha rada jeste utvrđivanje metodološkog okvira za benčmarking klasterskih organizacija u Srbiji. Proučavanje procesa formiranja, funkcionisanja i razvoja klasterskih organizacija, kao i postojećih benčmarking metodologija klasterskih organizacija u Evropi, iskorišćeno je za postavljanje prilagođenog metodološkog okvira za benčmarking u ovom radu. Upotrebna vrednost prikazane metodologije verifikovana je kroz komparativnu studiju dve klasterske organizacije u Srbiji. Rezultat ove benčmarking analize klastera predstavlja, između ostalog, $i$ determinisan set mera $i$ akcija za poboljšanje performansi Medical Start up klasterske organizacije. Istrazivanje je korisno ne samo kreatorima regionalnih razvojnih politika, jer pruža benčmarking metodologiju, već $i$ menadžmentu klasterskih organizacija u Srbiji koje dobijaju alat čija kontinuirana primena može da omogući unapređenje performansi članica klastera $i$ klasterske organizacije $u$ celini.

Ključne reči: klaster, performanse, benčmarking, proces, aktivnost

\section{Introduction}

Development of national and regional economies around the world has been largely fuelled by the appearance and activities of the clusters. Porter defines clusters as "geographic concentrations of interconnected companies and institutions in a particular field" (Porter, 1998). Generally, cluster organization is based on the principle of geographical concentration with increasing the innovative potential of all the related entities. Geographical co-location of companies has a positive effect on the business performances of the cluster members (Cortright, 2006). Improving business efficiency, greater market power and development potential are only part of the benefits brought by the cluster as a special form of organizational networking of entities in order to increase organizational/business, regional and national competitiveness.

Clusters in Serbia are still weak, and their importance is relatively small in terms of contribution to the country's competitiveness. The main weaknesses of Serbian cluster organizations are: (1) Lack of human resource management; (2) Lack of adequate infrastructure; (3) Lack of functional links between education, institutes and economy; (4) Inadequate funding of state aid or foreign aid for the initial forming phase of cluster organizations (Almeyda, 2008).

Nowadays, cluster policy becomes more important in almost all European countries. In order to align Serbia with this trend, there was a need for strategic 
Krstić D.B. et al.: Generic Benchmarking in the aim of Improving Clusters' ...

planning of the cluster development in the last decade. For this purpose, in 2012 LEDIB Cluster House conducted research in order to determine the number of active clusters and current stage of their development. Fifty five active clusters were identified in Serbia at the time of the research (Milojković, 2012).

In order to increase efficiency and, in particular, to reduce the rate of cluster liquidation in Serbia, organizational learning from the existing good practice is necessary. This can be accomplished by using the benchmarking method. Benchmarking can be considered as an excellent method of comparative performance measurement and analysis with the aim of competitiveness improvement (Shetty, 1993) and cluster development. However, there is a possibility to compare the processes/activities of forming, functioning and development in different cluster organizations.

The aim of this paper is to define the concept of the cluster organization's life cycle and point out the importance of cluster organizations' development in Serbia. The aim is to develop a conceptual framework of a benchmarking methodology for controlling the efficiency and directing the cluster development in Serbia, and then, to test the applicability of this methodology in order to improve current performances of the Medical Start up Cluster. The Vojvodina Metal Cluster (VMC) is used by Medical Start up Cluster, as the benchmarking partner or organization for comparison.

The purpose of this research is to provide a consistent methodological framework that can be applied by the management of other clusters in Serbia, and in particular, to identify actions for improving the existing performances of the Medical Start up Cluster. The use of generic benchmarking enables comparative analysis, although above mentioned clusters are in different areas of business activity. Therefore, a generic benchmarking or process benchmarking is used to identify necessary improvements of the forming, functioning, and development of the Medical Start up Cluster.

\section{Theoretical background}

\subsection{Cluster as a strategy for regional economy growth}

Basic characteristics of cluster organizations are reflected in the great interdependence of all cluster members, prompt diffusion of technological and managerial knowledge, entering into the strategic partnerships with suppliers and customers in order to achieve a synergistic effect on the level of each companymember and cluster organization as a whole. The objectives of the cluster organization are: (1) Establishment and development of common network of members; (2) Establishment of common strategy; (3) Facilitation of the 
Krstić D.B. et al.: Generic Benchmarking in the aim of Improving Clusters'...

development of innovations and introduction of new technologies; (4) Expansion of cluster and connecting with related cluster organizations (Volarev, 2010).

In literature, a special attention is given to clusters as a growth strategy of the regional economy. Regardless of size and formal links with other organizations, cluster enables a company to prosper without having to renounce its flexibility. Researches in the field of the cluster in Denmark show that $71 \%$ of cluster members increase their competitiveness. In order to strengthen the clusters in the region, there has been an increase of employment and raise of the specialization and the innovativeness level (Lamont Street Advisors, 2011). Cluster organizations affect competitiveness by increasing productivity within the cluster members. In developed European countries, cluster organizations are identified as the most relevant macroeconomic factor which influences the development of the region. About $38 \%$ of employees in the $\mathrm{EU}$ work for the companies that are members of a cluster (Commission of the European Communities, 2008).

The success of cluster organizations in meeting the goals and implementing the strategy is determined by many factors. This requires cluster management to continuously adjust thinking and align business strategy with the internal and external environment. Changes (innovations) that occur within the cluster organization or outside of it, can trigger the development and improvement in all stages of the cluster's life cycle.

The life cycle of cluster organization is analogous to the life of a human being (Adreozzi, 2010). However, phases of the life cycle of the cluster can be summarized as: (1) Forming of the cluster organization; (2) Functioning of the cluster organization; (3) Development of the cluster organization. Each of these complex phases or processes contains certain activities.

Control of processes, activities within them, and the achieved results of the cluster organization and its members, enables the reduction of risk and creation of opportunities for rapid growth and development (Cluster agroindustrial Ribatejo, 2012). Evaluating and assessing the performances of the cluster, isolated from performances of similar organizations, are significant, but comparison with similar organizations can better identify differences (performance deviations or gaps), which is the basis for redefining strategies and improving problematic business processes and activities (Krstić, 2013).

\subsection{Benchmarking in the aim of performance improvement, innovativeness and organizational learning}

Benchmarking is a systematic and continuous approach of measuring and comparing the performances of business processes, activities, products/services, strategies and practices of organizations in relation to other organizations with superior performances (Camp, 1995). Benchmarking is a solid base for 
Krstić D.B. et al.: Generic Benchmarking in the aim of Improving Clusters' ...

innovating, learning, and making changes in management practice and business activity (Cooper, 1995; Peradolo, 1998).

Benchmarking has proven to be an excellent tool for improving the performances of cluster organization through continuous comparison with the best practice cluster in the industry/region (Clusters \& Cooperation for Regional Development in Central Europe, 2013). Benchmarking can be "integrated into the strategic management of the cluster... Benchmarking provides policy makers and program agencies with valuable information about cluster performance" (ESCA, 2013).

The benefits of benchmarking are numerous for an organization which continuously and meticulously implements it. One of the key features of benchmarking is to assess and control the achieved operating performances. Benchmarking should be a continuous process (Krstić, 2012). This function becomes more important because an organization can adapt its behavior, according to dynamic environment based on the obtained results of comparative analysis (Bendell, 1997).

Benchmarking of performances is a complex methodological approach. It is not simply a quantitative comparison of individual business performances of two entities, but a deeper analysis of the causes and factors that affect or affected their business performances (Walleck, 1991). Benchmarking methodology is composed of a number of phases and the activities within them (Brownlie, 1999). However, any organization can create its own benchmarking methodology, according to available resources and, especially, requirements for management information (Krstić, 2001a; Krstić 2001b).

The literature usually emphasizes the following phases as the basis for benchmarking studies (Krstić, 2001c): (1) Planning the benchmarking study; (2) Collecting the necessary data and creating the information base with (a) cluster outcomes (employment, productivity, wages, profits, turnover, exports, etc), (b) cluster-specific drivers of growth and (c) cluster framework conditions (human resourcess, cooperation between universities and companies, entrepreneurship, knowledge sharing, etc.) (Andersen, 2007); (3) Data analysis and identification of differences (deviations, gaps) in the compared business performances; (4) Performance improvements program determination and its implementation in the upcoming period (Krstić, 2013).

There is no unique benchmarking methodology in business practice (Coopers and Lybrand Europe, 1994). Due to the flexible and the jagged structure of a cluster, benchmarking study is further complicated. The following paragraphs present some very well-known benchmarking methodology of cluster organizations in Europe.

Growing number of clusters use the ESCA methodology. European Secretariat for Cluster Analysis (ESCA) has developed a methodology that has been used by more than 450 clusters since 2008. The ESCA benchmarking methodology is 
Krstić D.B. et al.: Generic Benchmarking in the aim of Improving Clusters'...

based on a set of 36 indicators in five categories. The data needed for benchmarking analysis are obtained through in-depth interviews with the cluster managers (Hantsch, 2013a).

The national benchmarking methodology in Poland has been developed by experts in the field of clusters (The Public Sector Team of Deloitte, 2010). This methodology includes 85 indicators. According to this methodology, key benchmarking areas are: (1) Resources; (2) Processes; (3) Business performances; (4) Growth potential; and (5) Strategy of cluster organization.

A Norwegian IKT benchmarking study has made focus on more dimensions of the cluster: (1) Structure; (2) Financing; (3) Marketing activities; (4) Processes; (5) Internationalization; (6) Performances of the cluster. A set of 47 indicators is defined within these key areas (The Public Sector Team of Deloitte, 2010).

This study doesn't use all existing cluster benchmarking methodologies. At first glance, the benchmarking methodologies in Europe have a similar focus and tend to the overall improvement of cluster organizations in several key dimensions. Another common feature of the studied European benchmarking methodologies is the static. In addition, these methodologies provide an examination of the cluster performances at a given point in time.

\section{Research methodology}

The research performed in this paper is conducted based on the method of external, generic (or process) benchmarking. It includes a comparison of similar business processes and activities in unrelated organizations, which are not competitors (Krstić, 2013). Generic (or process) benchmarking uses non-financial indicators, and it uses process or activity based performance indicators (Krstić, 2012).

Study further elaborates examples of benchmarking methodologies which is used in Europe. These methodological frameworks served as the base for authors of this paper to create an original methodological framework and design the system of indicators with the purpose of comparing the selected clusters in Serbia. Previously summarized European benchmarking methodologies consider cluster organization at a certain moment in time, in fact at the time of performing benchmarking study and analysis. Our study emphasizes the dynamic benchmarking analysis of cluster organization in general, and changes in cluster performances throughout process scanning such as: cluster forming, cluster functioning and cluster development.

When examining clusters in Serbia, we have identified a large and unused development potential of the Medical Start up Cluster (greater number of successful members, significant potential for the medical tourism development in 
Krstić D.B. et al.: Generic Benchmarking in the aim of Improving Clusters' ...

the region, etc.). Therefore, the subject of the benchmarking study in this paper are performances of the Medical Start up Cluster from Niš generated in the processes (activities) of forming, functioning and development of the cluster organization. Corresponding indicators are identified for each performance of activities which are compared. The methodology in this study emphasized the vital set of 46 indicators for performing comparative measurement and analysis.

Benchmarking partner or organization with which the comparison is going to be done is the Vojvodina Metal Cluster (VMC) from Temerin. The VMC is, according to the basic criteria for the selection of benchmarking partner, identified as the cluster with the best performances in the state, based on the following: (a) Superior performance of processes and activities (which provided financing from the EU IPA project); (b) Rank list of the most successful organizations according to assesment of reputable professional associations, institutes, experts; (c) Quality and business excellence awards; (d) Positive publicity.

Although the so-called benchmarking partner or entity with which the comparison is done, is not in the same industry, it is considered that the VMC demonstrated superior performances and high quality of processes (Hantsch, 2013b). Consequently, the VMC can be considered adequate for the Medical Start up Cluster in the aim of learning and improvement activities' performances in the 3 vital processes - forming, functioning and development. The benchmarking study carried out in this research is based on the following general principles: (a) The principle of analogy and comparability, (b) The principle of adequate comparative measurement, and (c) The principle of the same time horizon of measurement and analysis.

The research uses primary data sources based on in-depth interviews. The questionnaire consists of 46 questions for assessing 46 indicators of activity performances. Secondary research leads to the all other relevant information that are going to allow a clearer and broader picture of the development of aforementioned clusters, their members and their business activities.

After collecting the necessary data for comparatible measurement and analysis, we have done the following: (1) Preparation and graphical presentation of data; (2) Alignment of data and performance indicators for comparison; (3) Comparison of indicator values for each of the observed activities; (4) Identification of deviations (gaps) and identification of the cause of critical or weak activity performance; (5) Identification of activities that need to be improved, and determining recommendations for improving critical process/activity performance; (6) Consideration of the possibilities how obtained study results can be applied in the function of performance improvement in compared cluster organizations in the future. 
Krstić D.B. et al.: Generic Benchmarking in the aim of Improving Clusters'...

Table 1. Indicators of activity performances within the process of forming, functioning and developing the cluster organization - recommended framework of benchmarking instrumentarium

\begin{tabular}{|c|c|c|c|c|}
\hline \multirow{2}{*}{ Number } & \multirow{2}{*}{ Indicators of activities } & \multicolumn{3}{|c|}{ The level of performance } \\
\hline & & $\mathbf{x}$ & \begin{tabular}{l|l}
$x \mathbf{x}$ & \\
\end{tabular} & $\mathbf{x x x}$ \\
\hline P1 & \multicolumn{4}{|l|}{ THE PROCESS OF FORMING CLUSTER ORGANIZATION } \\
\hline A1 & \multicolumn{4}{|l|}{ Analysis of potential of cluster organization } \\
\hline 11 & $\begin{array}{l}\text { The existence of the team during the formation of at least three } \\
\text { experts }\end{array}$ & 3 experts & From 4 to 10 & More than 10 \\
\hline 12 & Performed expert analysis of the potential of cluster organization & Initial analysis & Analysis - turning & Analysis - direction \\
\hline 13 & $\begin{array}{l}\text { Identified at least three strengths (S) and three weaknesses (W) of } \\
\text { the cluster }\end{array}$ & $3 \mathrm{~S}$ and $3 \mathrm{~W}$ & From 4 to 10 & More than 10 \\
\hline A2 & \multicolumn{4}{|c|}{ Plugging-up the environment, sensitization and identification of stakeholders } \\
\hline 14 & \begin{tabular}{|l|l|} 
Identification of key stakeholders - partners & \\
\end{tabular} & Up to 10 & From 11 to 20 & More than 20 \\
\hline 15 & Held the initial meeting - the number of participants & Up to 20 & From 21 to 40 & More than 40 \\
\hline 16 & $\begin{array}{l}\text { Held the initial workshop for potential members - the number of } \\
\text { participants }\end{array}$ & Up to 30 & From 31 to 60 & More than 60 \\
\hline 17 & Conducted SWOT analysis of clusters & Management & Membership & Expert team \\
\hline A3 & \multicolumn{4}{|c|}{ Developing strategies and objectives of the cluster organization } \\
\hline 18 & Created the vision and mission of the cluster organization & Management & Membership & Expert team \\
\hline 19 & Defined set of objectives cluster organization & Management & Membership & Expert team \\
\hline 110 & Adopted the strategy of cluster organization & Management & Membership & Expert team \\
\hline A4 & \multicolumn{4}{|l|}{ Creating business plan and financing plan } \\
\hline 111 & Made business plan of cluster organization & $\begin{array}{c}\text { Projection } \\
1 \text { year }\end{array}$ & $\begin{array}{c}\text { Projection } \\
3 \text { years }\end{array}$ & $\begin{array}{l}\text { Projection } \\
5 \text { years }\end{array}$ \\
\hline 112 & Made action plan of cluster organization & Management & Membership & Expert team \\
\hline 113 & Made financial plan and accompanying documentation & Management & Membership & Expert team \\
\hline A5 & \multicolumn{4}{|l|}{ Building and structuring of cluster organization } \\
\hline 114 & Selected legal form for registration of cluster & Private firm & Association & Combination \\
\hline 115 & Created organizational sheme of the cluster organization & Management & Membership & Expert team \\
\hline 116 & $\begin{array}{l}\text { The number of members of cluster organization - number of } \\
\text { members after establishment }\end{array}$ & Up to 50 & From 51 to 100 & More than 100 \\
\hline 117 & Number of partner organizations/institutions - in establishment & Up to 3 & From 4 to 10 & More than 10 \\
\hline A6 & \multicolumn{4}{|l|}{ Registration of cluster organization - form and procedure } \\
\hline 118 & Registration in the competent authorities & Informally & $\begin{array}{l}\text { In the registration } \\
\text { phase }\end{array}$ & Registered \\
\hline 119 & Made Statute of the organization & Management & Membership & Expert team \\
\hline $\mathbf{P 2}$ & \multirow{2}{*}{\multicolumn{4}{|c|}{$\begin{array}{l}\text { THE PROCESS OF CLUSTER ORGANIZATION FUNCTIONING } \\
\text { Creating a set of common services and activities of the cluster }\end{array}$}} \\
\hline A7 & & & & \\
\hline 120 & \begin{tabular}{|l|l} 
The number of services in the portfolio & \\
\end{tabular} & In preparation & Up to 10 & More than 10 \\
\hline 121 & $\begin{array}{l}\text { The structure of service in portfolio - the dominant nature of the } \\
\text { services }\end{array}$ & Promotion & Education & Profession \\
\hline $\mathbf{A 8}$ & \multicolumn{4}{|l|}{ Activities of project management } \\
\hline 122 & Number of projects implemented & Up to 10 & From 11 to 30 & More than 30 \\
\hline 123 & The existence of a permanent project team & Working group & $\begin{array}{l}\text { Team in the } \\
\text { formation }\end{array}$ & There is the team \\
\hline 124 & The results of the project activities & Promotion & $\begin{array}{l}\text { Education of } \\
\text { members }\end{array}$ & $\begin{array}{l}\text { Larger business } \\
\text { power of members }\end{array}$ \\
\hline A9 & \multicolumn{4}{|c|}{ Winning the partners and expanding the membership of the cluster organization } \\
\hline 125 & Number of signed Memorandum of cooperation with organizations & Up to 10 & From 11 to 20 & More than 20 \\
\hline 126 & Number of partner organizations - at the end of the period & Up to 5 & From 6 to 10 & More than 10 \\
\hline 127 & Number of cluster members - at the end of the period & Up to 50 & From 51 to 100 & More than 100 \\
\hline A10 & \multicolumn{4}{|l|}{ Marketing communications and public relations } \\
\hline 128 & The existence of a marketing plan & Management & Membership & Expert team \\
\hline 129 & Number of events in which the cluster is presented & Up to 10 & From 11 to 20 & More than 20 \\
\hline 130 & Number of used marketing tools & Up to 5 & From 6 to 10 & More than 10 \\
\hline 131 & Number of channels used for marketing communication & Up to 5 & From 6 to 10 & More than 10 \\
\hline
\end{tabular}




\begin{tabular}{|c|c|c|c|c|}
\hline $\mathbf{P 3}$ & THE PROCESS OF CLUSTER ORGANIZATION DEVELOPMENT & & & \\
\hline A11 & Improving marketing and brand development of cluster organiz & zation & & \\
\hline 132 & Brand identity - national or international & Regional & National & International \\
\hline 133 & Awards of cluster and advertisment in the media & PR advertisment & $\begin{array}{l}\text { Awards - the } \\
\text { profession }\end{array}$ & Award and PR \\
\hline 134 & 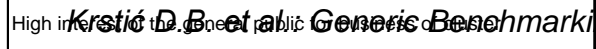 & 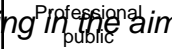 & afehengorouvin & 'thequstedeneral \\
\hline 135 & The existence of cluster "ambassadors" - known to the public & Up to 5 & From 6 to 10 & More than 10 \\
\hline 136 & Using the expanded set of marketing tools & Up to 2 channels & From 3 to 5 & More than 5 \\
\hline A12 & Change management within the cluster organization & & & \\
\hline 137 & Application of benchmarking analysis & Locally & Nationally & Internationally \\
\hline 138 & The motivation of management to initiate changes & Low level & Intermediate level & High level \\
\hline 139 & Ways to meet members with the changes in the cluster & Electronic & Regular meetings & Both \\
\hline A13 & Learning as a way of cluster organization development & & & \\
\hline 140 & Number of conducted training for members/cluster management & Up to 10 & From 11 to 30 & More than 30 \\
\hline 141 & Number of conducted training for partners & Up to 5 & From 6 to 10 & More than 10 \\
\hline 142 & Number of study visits & Up to 5 & From 6 to 10 & More than 10 \\
\hline 143 & Number of organized events & Up to 10 & From 11 to 30 & More than 30 \\
\hline A14 & Continuous control within the cluster organization - control an & d monitoring & & \\
\hline 144 & $\begin{array}{l}\text { The existence of the team for monitoring and/or evaluation of the } \\
\text { cluster work }\end{array}$ & Working group & $\begin{array}{l}\text { Team in the } \\
\text { formation }\end{array}$ & There is the team \\
\hline 145 & The involvement of external evaluators & At times & Periodically & Constantly \\
\hline 146 & Report on the monitoring and/or evaluation & Informal & Management & Expert team \\
\hline
\end{tabular}

Source: Author's calculation

In order to facilitate the application of this benchmarking methodology, a questionnaire and the "key" for its analysis and interpretation are designed. During data collection, particularly for qualitative questions, it is necessary to know the meaning of an indicator and the reasons for its control. Quantitative indicators are self-explanatory and always indicate better performance in the questionnaire if they have higher value (Table 1). Further, in the text, we explain some of the indicators presented in Table 1.

Within the activities $A_{1}$ we collect data about the following: a) the number of professional teams working on the analysis what determines its multidisciplinary (indicator $\mathrm{I}_{1}$ ), b) the detail of the analysis - whether the result is initial analysis of the potential and indicates the necessity of a shift in direction, or even changing the direction in which cluster develops (indicator $\mathrm{I}_{2}$ ), and c) the comprehensiveness of this analysis through the number the strengths and weaknesses of the organization explained in detail (indicator $I_{3}$ ).

The activity $A_{2}$ in addition to quantitative indicators, implies a SWOT analysis of the organization in which it is necessary for the researcher to examine whether SWOT analysis is compiled by the cluster management (the worst result) or membership is included in the analysis (better result) or hired a team of experts (the best result) (indicator $\mathrm{I}_{7}$ ).

The same evaluation of performances within indicator $\mathrm{I}_{7}$ occurs in all indicators within activity $A_{3}$.

Activity $A_{4}$ perceives professionalism in the field of planning, and corresponding $\mathrm{I}_{11}$ indicator shows the importance of long-term planning of activities in order to improve the cluster performance.

Organisational form of cluster $\left(A_{5}\right)$ assumes that a cluster organization with the legal form of a Private company (the consortium) achieves the worst performances, Association achieves better performances, while a Combination of these two achieves the best results - formed association with the company 
Krstić D.B. et al.: Generic Benchmarking in the aim of Improving Clusters'...

registration through which all common business of cluster organization can be manifested. Other indicators of $A_{5}$ activity indicate a positive character of strength in the formation of the cluster organization, so that a greater number of members and partner organizations has higher value.

The higher number of perceived indicators within the process of functioning of the cluster organization is shown quantitatively, where the increased value of the indicator implies a higher level of performance. Performance indicators relating to the structure of services in the cluster portfolio $\left(I_{21}\right)$ and the results of project activities $\left(\mathrm{I}_{24}\right)$ indicate the importance in terms of members and their progress, so that the activities associated with the promotion has the minimum value, education of membership has a higher value for better performance of members and cluster organization in general, while the most important are services in the profession that increase business capacity of a firm (the introduction of standards, equipment, innovative activities).

Quantitative indicators within the indicator of the development process of cluster organization also aspire to higher values in the case of a higher level of observed performances. Qualitative indicators determine the location and structure of the target group to which the cluster organization addresses $\left(I_{32}, I_{34}\right)$, the use of awards and achievements in public relations (PR) purposes $\left(I_{33}\right)$, and the inclusion of a large number of people known to the public from different areas in the promotion of clusters and such ways of associating $\left(\mathrm{I}_{35}\right)$.

The activity $A_{12}$ shows that the change should be managed using a benchmarking analysis of the wider context $\left(\mathrm{I}_{37}\right)$, with higher levels of motivation of the management team $\left(\mathrm{I}_{38}\right)$ and that the membership of cluster organization should meet the changes occurring or which are going to occur through many communication channels $\left(\mathrm{I}_{39}\right)$.

The cluster organization as a learning organization - activity $A_{13}$ indicates the importance of the realization of a large number of events that will initiate studies of cluster members and management (from $\mathrm{I}_{40}$ to $\mathrm{I}_{43}$ ).

It is estimated that the forming of own team or, in the inability of this, forming of working group $\left(\mathrm{I}_{43}\right)$ is the best for monitoring and evaluation activities $\left(\mathrm{A}_{14}\right)$. These activities should be carried out frequently and consistently $\left(\mathrm{I}_{45}\right)$, and reporting on monitoring should be formal and professional $\left(\mathrm{I}_{46}\right)$ in order to control and improve the performance of cluster organization.

The benchmarking methodological framework developed for purposes of this study differentiates disparate levels of activity performances, marked in Table 1 with * - the lowest level of performance, ** - medium level of performance, ** the highest level of performance. The reason for differentiating levels of performance is to evaluate differences (deviations) in performances when we compare two organizations. Significant differences exist when an organization 
Krstić D.B. et al.: Generic Benchmarking in the aim of Improving Clusters' ...

shows the level of performance - *, and the second organization shows the highest level of performance $-* \star \star$ (Table 2 ).

Table 2. Combination of performance values in benchmarking study of cluster organizations (Medical Start-up and the VMC)

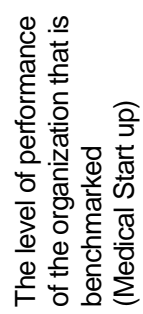

*** \begin{tabular}{|c|c|c|}
\hline $\begin{array}{c}\text { The strongest } \\
\text { performance }\end{array}$ & Strong performance & Matching \\
\hline $\begin{array}{c}\text { The strong } \\
\text { performance }\end{array}$ & Matching & Tracking \\
\hline Matching & Tracking & $\begin{array}{c}\text { The weakest } \\
\text { performance }\end{array}$ \\
\hline
\end{tabular}
***

The level of performance of the organization that is considered as "standard" for comparison (VMC)

Source: Author's calculation

The strongest performance - Performances of benchmarked cluster (the Medical Start up) which are by two degrees higher than the standard (benchmark - the VMC). These performances should continue to foster and develop and make the core of the cluster competitiveness.

Strong performance - Performances of cluster (the Medical Start up) that are one step higher than the compared standard (the VMC). The cluster must continue to develop these performances and fully exploit their potential in a competitive match.

Matching - How cluster organizations exist and operate in the same conditions (legal framework, the limits of economic policy, etc.), it may be that some performances have the same value. These performances can not or do not need to change.

Tracking - Performances accompanying values of cluster organization with which performance comparison is done (the VMC) are those that show a delay, but not drastically. There is the possibility of performance improvement. However, depending on the significance of the performance of the business processes of cluster organization (the Medical Start up), management will decide whether the performance gain priority in the recommendations and planned measures for improvement.

The weakest performance - This performance shows a negative deviation (the Medical Start Up) by two degrees compared to the standard (the VMC). This performance is a priority for correcting and it is going to need the most attention in planning and management of change in the future. 
Krstić D.B. et al.: Generic Benchmarking in the aim of Improving Clusters'...

The importance of performances, size of variations and their combinations, scanned for all 46 indicators, can be used to define the order (priority list) for improving the performances of activities and defining programs, initiatives and strategies for their improvement.

Based on the defined objective of this research, and presented the methodological framework, the following research question or hypothesis is formulated and tested:

Recommended methodological framework of generic/process benchmarking of cluster organizations' performances in Serbia gives good results in terms of quality of management information for the cluster management and other relevant stakeholders in the function of improving critical processes, business efficiency and direct future development policy.

\section{Research results, discussion and implications for management}

The $V M C$ is a non-profit, non-governmental, non-party network of voluntary and interest related legal and individual entities in the metal sector in Vojvodina. The cluster is established through the IPA project worth about $862.006 €$, out of which $85.81 \%$ are EU grants and $14.19 \%$ are resources of partners (the Vojvodina province). Project duration has been 24 months (2011-2012). The cluster operates independently fulfilling its goals after this period.

Medical Start up is a non-profit and non-party network of private practices in the areas of health care, as well as the network of organizations which are responsible for the support of cluster functioning and development (for example marketing, education, and research organizations). The cluster has been established in January 2010, with the technical support of the Danish program for Local Economic Development in the Balkans - LEDIB.

Data collected from the members of the management team of the Medical Start up Cluster and the VMC is shown in Table 3, 4 and 5. Comparison between the Medical Start up Cluster and the VMC, that has determined negative deviations (gaps) in the process/activity performance, is done based on the measured value of 46 performance indicators.

The values of negative deviations of higher level (greater extent), which will be the focus of this paper, are highlighted with bold signs and letters in Tables 3, 4 and 5. Benchmarking instrumentation of the 46 indicators is classified in three main processes - forming, functioning and development of the cluster, and in 14 sub-area $\left(A_{1}-A_{14}\right)$ within these processes. Tables 3,4 and 5 show the values of qualitative/quantitative performances obtained through the questionnaire, and so- 
Krstić D.B. et al.: Generic Benchmarking in the aim of Improving Clusters' ...

called level of performances is marked below them, on the basis of the "key" prepared in advance in Table 1.

Although the data in table 3 shows the largest number of deviations (performance gaps) in the process of cluster forming, even 17, this data should not be taken without considering the overall status and conditions of forming these clusters. It can be stated, in terms of a generic (or process) benchmarking, that the Medical Start up Cluster has realized the most of the activities in this process, but with different volume (smaller) than the VMC.

Deviations in the following activities' performance of the Medical Start up compared with the VMC are identified in the forming of the cluster organization:

$\mathbf{A}_{1}$ ) Fewer members of the professional team in the forming of the cluster organization indicates the reduced level of multidisciplinary and reduced value of adopted conclusions; Expert analysis of the potential cluster analysis is not performed since it has been done done in the case of the VMC by engaging local agencies, and based on these results, the strategy of the organization with supporting objectives has been developed; A large number of identified strengths and weaknesses of the cluster allow understanding the potential of the cluster organization and its competitive advantage (see Table 3 ).

$\mathbf{A}_{2}$ ) Identification of partners is going to help in forming networks and connecting with them in the near future, and therefore this is a very important indicator. Meetings of founders enable creation of a strong cluster organization with realistic expectations and correctly accepted rights and obligations.

In order to obtain dedicated new members, it is necessary to conduct a workshop for potential members. Implementation of professional SWOT analysis is also necessary. In addition to quantitative differences due to discrepancies in the way of forming (the VMC has been created from an existing MEMOS cluster), the largest failure of the Medical Start up Cluster in activity $A_{2}$ is lack of commitment to potential members. Also, SWOT analysis has been done by membership with the help of the managers and facilitators, which can have their own shortcomings.

$A_{3}$ ) Drastic negative deviations in the activities of the strategy development and objectives of the cluster organization have been created as a result of their implementation of cluster management, without the cooperation of the membership and expert team, which can cause significant problems due to the lack of well-designed strategy and/or objectives of the organization. This indicates a low level of professionalism of the Medical Start up Cluster, caused primarily by lack of financial resources to hire a professional team to plan, manage and control. 
Krstić D.B. et al.: Generic Benchmarking in the aim of Improving Clusters'...

Table 3. Benchmarking activities of the Medical Start up Cluster with the VMC in the process of forming a cluster organization

\begin{tabular}{|c|c|c|c|}
\hline 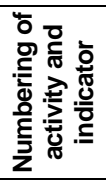 & $\begin{array}{l}\text { Performance indicators of activities within the process } \\
\text { of cluster forming }\end{array}$ & VMC & $\begin{array}{l}\text { Medical Start } \\
\text { up }\end{array}$ \\
\hline A1 & \multicolumn{3}{|l|}{ Analysis of potential of cluster organization } \\
\hline 11 & $\begin{array}{l}\text { The existence of the team during the formation of at least three } \\
\text { experts }\end{array}$ & $\begin{array}{l}5 \\
* *\end{array}$ & $\begin{array}{l}3 \\
*\end{array}$ \\
\hline 12 & $\begin{array}{l}\text { Performed an expert analysis of the potential of cluster } \\
\text { organization }\end{array}$ & $\underset{* *}{\text { Initial }}$ & I \\
\hline 13 & $\begin{array}{l}\text { Identified at least three strengths and three weaknesses of the } \\
\text { cluster }\end{array}$ & $\underset{\star \star \star}{\text { More than } 10}$ & $\begin{array}{ll}5 \\
* \star\end{array}$ \\
\hline$A 2$ & \multicolumn{3}{|l|}{$\begin{array}{l}\text { Plugging-up the environment, sensitization and } \\
\text { identification of stakeholders }\end{array}$} \\
\hline 14 & Identification of key stakeholders - partners & From 10 to 20 & $\begin{array}{c}10 \\
*\end{array}$ \\
\hline 15 & Held the initial meeting - the number of participants & From 21 to 40 & $\begin{array}{c}20 \\
*\end{array}$ \\
\hline 16 & $\begin{array}{l}\text { Held the initial workshop for potential members - the number of } \\
\text { participants }\end{array}$ & $\underset{* *}{\text { From }} 31$ to 60 & I \\
\hline 17 & Conducted SWOT analysis of clusters & $\underset{\star \star x}{\text { Expert team }}$ & $\underset{\star \star}{\text { Membership }}$ \\
\hline A3 & \multicolumn{3}{|l|}{$\begin{array}{l}\text { Developing strategies and objectives } \\
\text { of the cluster organization }\end{array}$} \\
\hline 18 & Created with the vision and mission of the cluster organization & $\underset{\star \star \star *}{\text { Expert team }}$ & $\underset{*}{\operatorname{Management}}$ \\
\hline 19 & Defined set of objectives of cluster organization & $\underset{\star \star \star}{\text { Expert team }}$ & $\underset{*}{\operatorname{Management}}$ \\
\hline 110 & Adopted the strategy of cluster organization & $\underset{\star \star \star *}{\text { Expert team }}$ & $\underset{*}{\operatorname{Management}}$ \\
\hline A4 & \multicolumn{3}{|l|}{ Creating business plan and financing plan } \\
\hline I 11 & Made business plan of cluster organization & $\begin{array}{l}\text { Projection }-2 \\
\text { years } \\
\star \star\end{array}$ & I \\
\hline 112 & Made an action plan of cluster organization & $\underset{\star \star x}{\text { Expert team }}$ & $\underset{\star \star}{\text { Membership }}$ \\
\hline 113 & Made financial plan and accompanying documentation & $\underset{\star \star \star \star}{\text { Expert team }}$ & $\underset{*}{\text { Management }}$ \\
\hline A5 & \multicolumn{3}{|l|}{ Building and structuring of cluster organization } \\
\hline I 14 & Selected legal form for registration of VMC & $\underset{\star \star}{\text { Association }}$ & $\underset{\star \star}{\text { Association }}$ \\
\hline I 15 & Created organizational scheme of the cluster organization & $\underset{* \star *}{\text { Expert team }}$ & $\underset{*}{\operatorname{Management}}$ \\
\hline I 16 & $\begin{array}{l}\text { The number of members of cluster organization - number of } \\
\text { members after establishment }\end{array}$ & $\begin{array}{l}76 \\
\star * \\
\end{array}$ & $\begin{array}{c}27 \\
* \\
\end{array}$ \\
\hline 117 & Number of partner organizations/institutions - in establishment & 16 & $\begin{array}{l}3 \\
*\end{array}$ \\
\hline$A 6$ & \multicolumn{3}{|l|}{$\begin{array}{l}\text { Registration of cluster organization - form } \\
\text { and procedure }\end{array}$} \\
\hline । 18 & Registration in the competent authorities & $\underset{\star \star \star}{\text { Registered }}$ & $\underset{\star \star \star \star}{\text { Registered }}$ \\
\hline I 19 & Made Statute of the organization & $\underset{* \star *}{\text { Expert team }}$ & $\underset{*}{\operatorname{Management}}$ \\
\hline
\end{tabular}

Note: Sign "/" means that activity is not realized

Source: Author's calculation 
Krstić D.B. et al.: Generic Benchmarking in the aim of Improving Clusters' ...

$\mathbf{A}_{4}$ ) Planning is the base of any strategic or tactical step of cluster organizations. The lack of a business plan, with partial professional planning activities and financial flows of the cluster organization, imply an unsatisfactory professionalism level of the Medical Start up Cluster, and a lack of funds. Operational planning without projection is not enough to create a strong base for further upgrade of the cluster organization.

$\mathrm{A}_{5}$ ) Both clusters are registered as associations, with the difference in the number of members and partner organizations. As the VMC came from the MEMOS cluster, the number of members can be considered as irrelevant for the observed benchmarking analysis. Also, the number of partner organizations does not reflect the true situation, since the Medical Start up Cluster is formed by "bottom - up" principle, the initial inclusion which legally requires a number of partners (three organizations) can be considered as acceptable. Organizational scheme of organization has been created without any professional help, but as the Medical Start up has been supported by the Danish LEDIB program and their professional team in the initial activities, we can consider that this activity is carried out in accordance with the highest standards.

$\mathbf{A}_{6}$ ) Both cluster organizations are registered in the Business Registers Agency. Deviation in activities $A_{6}$ occurs at the level of professionalism in the preparation of the Statute of the organization. Management made the Statute of the Medical Start up Cluster, while hired a professional team has made the Statute of the VMC.

In order to improve the work of the Medical Start up Cluster organization, based on the observed deviations (gaps), we come to the following implications for the management of cluster organization, related to the activities of the forming process of cluster organization:

- The involvement of a multidisciplinary expert team in the implementation of key activities;

- Greater professionalization of process and the management team (paid and trained management team, hiring consultants according to need);

- Professional creating of strategies and plans for the cluster organization with the monitoring and necessary modifying activities planned by them;

- Commitment to potential and/or new members (raising awareness and motivation, creating dedicated members through regular meetings and training);

- Identification and involvement of partner organizations (public, scientific research). 
Krstić D.B. et al.: Generic Benchmarking in the aim of Improving Clusters'...

Table 4. Benchmarking activities of the Medical Start up Cluster with the VMC in the process of cluster organization functioning

\begin{tabular}{|c|c|c|c|}
\hline 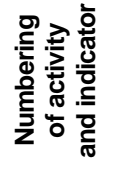 & $\begin{array}{l}\text { Performance indicators of activities within } \\
\text { the cluster functioning }\end{array}$ & VMC & $\begin{array}{l}\text { Medical Start } \\
\text { up }\end{array}$ \\
\hline$A 7$ & $\begin{array}{l}\text { Creating a set of common services and } \\
\text { activities of the cluster }\end{array}$ & & \\
\hline 120 & The number of services in the portfolio & $\underset{\star}{\text { In construction }}$ & 18 \\
\hline 121 & $\begin{array}{l}\text { The structure of service in portfolio - the dominant nature of the } \\
\text { services }\end{array}$ & $\underset{* \star \star}{\text { Profession }}$ & $\underset{\star \star \star}{\text { Education }}$ \\
\hline A8 & Activities of project management & & \\
\hline 122 & Number of projects implemented & $\begin{array}{l}5 \\
*\end{array}$ & $\begin{array}{l}15 \\
\text { ** }\end{array}$ \\
\hline 123 & The existence of a permanent project team & $\underset{\star \star \star *}{\text { There is }}$ & I \\
\hline 124 & The results of the project activities & $\begin{array}{c}\text { Larger } \\
\text { business power } \\
\text { of members } \\
\star \star \star\end{array}$ & $\begin{array}{c}\text { Educated } \\
\text { membership } \\
\star \star\end{array}$ \\
\hline$A 9$ & $\begin{array}{l}\text { Winning the partners and expanding } \\
\text { the membership of the cluster organization }\end{array}$ & & \\
\hline 125 & $\begin{array}{l}\text { Number of signed Memorandum of cooperation with } \\
\text { organizations }\end{array}$ & 21 & $\begin{array}{l}9 \\
*\end{array}$ \\
\hline 126 & $\begin{array}{l}\text { Number of partner organizations - at the end of the two-year } \\
\text { period }\end{array}$ & 19 & $\begin{array}{l}5 \\
* \\
\end{array}$ \\
\hline 127 & Number of cluster members - at the end of the two-year period & 116 & $\begin{array}{ll}54 \\
* \star\end{array}$ \\
\hline$A 10$ & Marketing communications and public relations & & \\
\hline 128 & The existence of a marketing plan & 1 & 1 \\
\hline 129 & Number of events in which the cluster is presented & 22 & $\begin{array}{c}10 \\
\star *\end{array}$ \\
\hline 130 & Number of used marketing tools & $\begin{array}{l}7 \\
\star \star\end{array}$ & $\begin{array}{l}2 \\
\star\end{array}$ \\
\hline 131 & Number of channels used for marketing communication & $\begin{array}{c}6 \\
* \star\end{array}$ & $\begin{array}{l}4 \\
\text { * }\end{array}$ \\
\hline
\end{tabular}

Note: Sign "/" means that activity is not realized.

Source: Author's calculation

Deviations in the performance of the following activities are identified in the functioning of the cluster organization (see Table 4):

$\mathbf{A}_{7}$ ) Jagged portfolio of services in the Medical Start up Cluster has the disadvantage in terms of the predominant nature of the services - education of the membership. However, this type of service is considered very useful for members and cluster in general. Professional services and joint activities included in the cluster have greater importance for increasing business efficiency and effectiveness of the membership, and thus for the progress of clusters. This parameter applies to $A_{8}$ project activities in which increased business strength of 
Krstić D.B. et al.: Generic Benchmarking in the aim of Improving Clusters' ...

members is more significant than the education of the membership or their promotion.

$\mathbf{A}_{8}$ ) Regardless of the larger number of undertaken project activities, the lack of a permanent project team, or even pre-established working groups, stand out as significant negative deviation of the Medical Start up Cluster. This is correlated with an unfavorable financial situation and under-exploited potential of the cluster through the inclusion of individuals/experts from member companies and partner organizations (public and scientific - research sectors).

$\mathbf{A}_{\mathbf{g}}$ ) The gap in connecting with partner organizations has been further deepened in the functioning of the Medical Start up Cluster. Lack of dissection of partner networks (dramatically smaller number of signed memorandum of understanding and participating partner organizations at the end of the period) affects the reduced innovation and project potential in the observed clusters. Number of members at the end of the period is still less than the number of the VMC members, but is satisfactory with regard to the membership of the Medical Start up Cluster increased by 100\% (from 27 to 54 members) for a period of two years.

$A_{10}$ ) Both organizations have not created a marketing plan, and the undertaken marketing activities can be viewed as a set of ad-hoc activities that are directly related to the available budget and the capacity of cluster organizations. This is accompanied by negative deviations in terms of marketing efforts of the Medical Start up Cluster (number of events, used marketing channels and tools).

Based on the observed deviations, we have found the following implications for the management of the cluster organization in terms of the activities of the functioning process of the cluster:

- Completing the portfolio of services with a professional service, or with those services that would contribute to the strengthening of business power of the cluster organization (introduction of standards, networking with partners, etc.);

- Establishment of a permanent project team and project working groups Projects may represent an excellent source of financing for cluster organizations with realization of activities that could not be organized or financed independently;

- The internationalization of business and/or expanding the influence of the cluster organization from the regional to the national level through networking with partners and other clusters, and through the planned use of marketing tools for promoting of the organization;

- Increasing the number of partners with a balanced partnership portfolio is going to enable uniform and controlled development of clusters. Identifying and attracting a large number of partner organizations will increase the propulsion of the cluster organization and increase the chances of getting projects; 
Krstić D.B. et al.: Generic Benchmarking in the aim of Improving Clusters'...

- Increasing membership should be planned and targeted. The focus must be about winning and nurturing of the membership, otherwise merely increased number of members may even backfire, since it hinders communication, coordination, and often increases the heterogeneity of the membership;

- Increasing the number of marketing tools and channels. Recruitment of new members and investors is expected result.

Table 5 - Benchmarking activities of the Medical Start up Cluster with the VMC in the development process of cluster organization

\begin{tabular}{|c|c|c|c|}
\hline 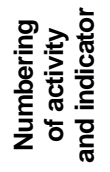 & $\begin{array}{l}\text { Performance indicators of activities } \\
\text { within the cluster development }\end{array}$ & VMC & $\begin{array}{l}\text { Medical Start } \\
\text { up }\end{array}$ \\
\hline A11 & \multicolumn{3}{|l|}{$\begin{array}{l}\text { Improving marketing and brand development } \\
\text { of cluster organization }\end{array}$} \\
\hline 132 & Brand identity - national or international & $\underset{* \star}{\text { National }}$ & $\underset{*}{\operatorname{Regional}}$ \\
\hline 133 & Awards of cluster and advertisement in the media & $\underset{* \star \star}{\text { Award and PR }}$ & $\underset{*}{\text { PR }}$ \\
\hline 134 & High interest of the general public for business of cluster & $\underset{* \star \star}{\text { General public }}$ & $\begin{array}{c}\text { Professional } \\
\text { public } \\
*\end{array}$ \\
\hline 135 & The existence of cluster "ambassadors" - known to the public & l & I \\
\hline 136 & Using the expanded set of marketing tools & I & $\underset{*}{2 \text { channels }}$ \\
\hline A12 & \multicolumn{3}{|l|}{ Change management within the cluster organization } \\
\hline 137 & Application of benchmarking analysis & $\underset{\star \star \star \star}{\text { Internationally }}$ & l \\
\hline 138 & The motivation of management to initiate changes & $\underset{* \star *}{\text { High level }}$ & $\underset{*}{\text { Low level }}$ \\
\hline 139 & Ways to meet members with the changes in the cluster & $\underset{* \star *}{\text { Both }}$ & $\begin{array}{c}\text { Electronic } \\
*\end{array}$ \\
\hline A13 & \multicolumn{3}{|c|}{ Learning as a way of cluster organization development } \\
\hline 140 & Number of realized training for members/cluster management & $\underset{\star \text { More than } 30}{* \star \star}$ & $\underset{\star \star}{\text { More than } 10}$ \\
\hline 141 & Number of realized training for partners & I & $\begin{array}{l}2 \\
*\end{array}$ \\
\hline 142 & Number of study visits & $\begin{array}{l}5 \\
*\end{array}$ & 1 \\
\hline 143 & Number of organized events (clubs, conferences, B2B) & 20 & I \\
\hline$A 14$ & \multicolumn{3}{|l|}{$\begin{array}{l}\text { Continuous control within the cluster } \\
\text { organization - control and monitoring }\end{array}$} \\
\hline 144 & $\begin{array}{l}\text { The existence of the team for monitoring and/or evaluation of } \\
\text { the cluster work }\end{array}$ & $\begin{array}{l}\text { There is the } \\
\text { team } \\
\star \star \star\end{array}$ & I \\
\hline 145 & The involvement of external evaluators & At times & I \\
\hline 146 & Report on the monitoring and/or evaluation & $\underset{* \star \star}{\text { Expert team }}$ & I \\
\hline
\end{tabular}

Note: Sign "/" means that activity is not realized.

Source: Author's calculation 
Krstić D.B. et al.: Generic Benchmarking in the aim of Improving Clusters' ...

However, it can be noted that performances with a negative deviation in the development process (Process 3 ) are not most numerous (11 out of 15 indicators). In addition, this process 3 has even $40 \%$ of not completed activities which implies the lack of strength for the further development (seeTable 5).

Deviations in the performance of the following activities have been identified in the development process of the cluster organization:

$A_{11}$ ) Negative deviations in the area of enhanced marketing efforts are reflected in the lack of planned, regional PR announcements. Also, the lack of work efficiency verification through the awards, which would complement the appeal to the general public, is recorded as a negative deviation from the standard (the VMC). While the VMC is recognized as a brand on a national level, the Medical Start up is perceived regionally and by experts.

$\mathbf{A}_{12}$ ) This activity is characterized by failure to use benchmarking analysis by the Medical Start up Cluster, while the VMC is one of the users of the ESCA benchmarking methodology; low levels of management motivation to initiate changes; and the one-sidedness in the reporting of future changes to membership. All this implies an insufficient capacity to anticipate and manage change as an important element for the survival and development of the cluster.

$\mathbf{A}_{13}$ ) Drastic deviations in $A_{13}$ activity indicate insufficient capability of the Medical Start up Cluster that acts as a "learning organization". Almost all of the performances of this activity have lower values than the benchmark: training for members/cluster management, study tours, organized events. However, the Medical Start up Cluster educated more than 500 members in the held training (this number is three times higher in the VMC). Also, there is the difference in the case of held training. Members of the medical cluster have usually attended professional training in the field of medicine, while the members of the VMC have been participants in educations from areas relevant to the overall improvement of the business (strategic and operational management, standards, electronic business).

$\mathbf{A}_{14}$ ) Unlike the Medical Start up Cluster, the management team of the VMC observes regular monitoring (monthly, quarterly, semi-annual and annual). Internal monitors, experts from partner organizations, observe monitoring, and submit a professional monitoring report to the authorities on several instances. Insufficient knowledge about the results of previously conducted activities in the Medical Start up Cluster is noted as a negative side of this deviation. The lack of constantly engaged staff and financial resources is the reason for this deviation.

Based on the observed deviations (gaps), we have come to the following implications for the management of cluster organization in respect of the cluster development process activities: 
Krstić D.B. et al.: Generic Benchmarking in the aim of Improving Clusters'...

- Design and brand development of cluster organization is going to contribute positively to the high recognition of the organization, easier attraction of new members and partners, creating a base for the internationalization of the organization;

- Increase internationalization of cluster organization through foreign market research, marketing activities and consequently entry foreign markets;

- Increase the innovation potential of the cluster organization through networking and collaboration with appropriate partner organizations (universities, scientific - research institutions, etc.);

- Improve business of the cluster organization through the use of benchmarking method and application in this way made recommendations (study results);

- Increase the motivation of cluster organization management, particularly in terms of initiating and managing change. The level of motivation can be raised by financial and non-financial compensation that cluster manager can achieve if implements changes at the agreed scope and time.

- Positioning the cluster as a "learning organization", through the diffusion of knowledge and exchange of experiences within the study tours and various events (B2B events, round tables, conferences, etc.).

- Mandatory monitoring and/or evaluation of cluster organization's work as a part of control is necessary for periodical revision of defined objectives and action plan in accordance with the new internal or external conditions.

\section{Conclusion}

The development of cluster organization in a turbulent business environment is determined by its ability to adapt and change. It is not possible to avoid the vulnerability of cluster organizations in the competitive struggle without monitoring, comparison and control. The application of benchmarking allows comparison and control of processes and associated activities of the cluster organization. Therefore, the conclusions of this study can contribute to better understanding of the application of the benchmarking method in this field and the possibilities of its use. Advanced level of understanding the importance and application of benchmarking would mean: observation of benchmarking as a tool to control the cluster organization strategy, forming a permanent benchmarking team within the organization, fostering partnerships in the industry or with the best clusters in the region or the world, and creating a positive public image.

There is no single benchmarking methodology in practice, in general. Keeping in mind the needs of cluster organization's management for information, we have 
Krstić D.B. et al.: Generic Benchmarking in the aim of Improving Clusters' ...

created a special methodological framework of benchmarking methodology, which applicability, appropriateness and usefulness is tested at the Medical Start up Clusters and the VMC. A report with the gaps in performance and recommended actions is communicated with the management team of the Medical Start up Cluster. It is confirmed that benchmarking report can be useful for planning changes in the identified critical activities of functioning and development phases. It is considered that the proposed actions are applicable, and that they can significantly improve operations of the Medical Start up Cluster in the future. We have confirmed the starting hypothesis this way. Identifying critical areas of activities/processes and formulating recommendations for their improvement, positively accepted by the management team of the Medical Start up Cluster, verify the usability and usefulness of the proposed methodology framework.

\section{References}

Adreozzi, B. (2010). Razvoj klastera. Beograd: Ministarstvo rada, zapošljavanja i socijalne politike.

Almeyda, P. (2008). Evaluation and Policy paper on the Current State of ResearchCommerce interfaces and Cluster in Serbia. Beograd: EPI - Techical support for Enterprsise Policy and innovation Project.

Andersen, T., Bjerre, M., \& Hansson, E.W. (2007). The Cluster Benchmarking Project. Nordic Innovation Centre. Retrieved from http://www.nordicinnovation.org/Global/ Publications/Reports/2007/The\%20clust er\%20benchmarking\%20project\%20-

\%20Benchmarking\%20clusters\%20in \%20the\%20knowledge\%20based\%20econ omy.pdf 2014 Mar 20.

Bendell, T., Boulter, L., \& Gatford, K. (1997). The Benchmarking Workout. Financial Times. Prentice Hall..

Brownlie, D. (1999). Benchmarking Your Marketing Process. Long Range Planning, 32(1), 88-95.

Camp, R.C. (1995). Business process benchmarking: Finding and implementing best practices. Wisconsin: ASQC Quality Press.

-Cluster agroindustrial Ribatejo. (2012). International Benchmarking study of competitiveness poles and cluster and identification of best practises. Retrieved from

http://www.vegepolys.eu/media/international benchmarking study inovisa pic $20120922995001147 \quad 26062012 . p d f 2014$ Mar 19.

-Clusters \& cooperation for Regional Development in Central Europe. (2013). Exchange of Expririence dedicated to the identification of good practices. In CENTRAL EUROPE Programme. Retrieved from http://www.central2013.eu/fileadmin/user upload/Downloads/outputlib/ClustersC ord Policy recommendations.pdf 2014 Mar 20.

Cooper, R.G., \& Kleinschmidt, E.J. (1995). Benchmarking the Firm's Critical Success Factors in the New Product Development. Journal of Product Innovation Management, 12, 347-391. 
Krstić D.B. et al.: Generic Benchmarking in the aim of Improving Clusters'...

-Coopers \& Lybrand Europe. (1994). Survey of benchmarking in Europe. London: Coopers and Lybrand.

Cortright, J. (2006). Making sense of clusters: Regional Competitiveness and Economic development. A Discussion Paper Prepared for the The Brookings Institution Metropolitan Policy Program. In A Discussion Paper Prepared for the The Brookings Institution Metropolitan Policy Program. Impresa, Inc..

-ESCA. (2013). Benchmarking as a tool for cluster Analysis. Retrieved from http://www.cluster-analysis.org/downloads/ESCA leaflet March2012.pdf 2014 Mar 20.

Hantsch, S., Kergel, H., \& Kind, S. (2013). Benchmarking report Klaster poljomehanizacije $d$. o. o.. Berlin: ESCA VDI/VDE Inovation; Berlin: Tehnik $\mathrm{GmbH}$.

Hantsch, S., Kergel, H., \& Kind, S. (2013). Benchmarking report Vojvodina Metal Cluster. Berlin: ESCA VDI/VDE Inovation; Berlin: Tehnik GmbH.

Krstić, B. (2001). Benčmarking - menadžment alat za povećanje efikasnosti poslovanja (I). Poslovna politika, 30, 46-52. Jun.

Krstić, B. (2001). Benčmarking - menadžment alat za povećanje efikasnosti poslovanja (II). Poslovna politika, 30, 45-51. Jul-Avgust.

Krstić, B. (2001). Benčmarking - menadžer alata za povećanje efikasnosti poslovanja (III). Poslovna politika, 30, 32-38. Septembar.

Krstić, B., \& Sekulić, V. (2012). Uloga strategijske kontrole u unapređenju poslovnih performansi. Niš: Ekonomski fakultet.

Krstić, B., \& Sekulić, V. (2013). Upravljanje performansama preduzeća. Niš: Ekonomski fakultet.

-Lamont Street Advisors. (2011). Cluster competetivness report 2011. Retrieved from www.ledib.org 2014 Feb 10

Milojković, D., Zlatković, G., \& Stojković, N. (2012). Clusters - Tools for achieving sustainable economic development.Nauka i praksa, 15, 95-100.

Petradolo, D. (1998). The "20 Keys" to Workplace Improvement. Industrial Management, 40(1), 22-28.

Porter, M. (1998). Clusters and the New Economics of Competition. Harvard Business Review, 77-89. November-December.

Shetty, Y. (1993). Aiming High: Competitive Benchmarking for Superior Performance. Long Range Planning, 26(1), 39-44.

-The Public Sector Team of Deloitte Business Consulting S.A.. (2010). Cluster Benchmarking in Poland - 2010. Polska Agencja Razwoju: Warsow. Retrieved from http://www.parp.gov.pl/files/74/81/380/9762.pdf 2014 Mar 20.

Volarev, T. (2010). Priručnik za osnivanje klastera u Republici Srbiji. Retrieved from http://data.sfb.rs/sftp/organizacija.sum 2014 Apr 10.

Walleck, A.S., O'Halloran, J.D., \& Leader, C.A. (1991). Benchmarking World-Class Performance. The McKinsey Quarterly,1(1), 3-24. 